\title{
Juvenile development of Callinectes ornatus Ordway, 1863 (Crustacea: Decapoda: Portunidae), from megalopae obtained in the neuston
}

\author{
EDUARDO ANTONIO BOLLA JÚNIOR, MARIA LUCIA NEGREIROS-FRANSOZO ${ }^{1}$ \\ \& ADILSON FRANSOZO \\ Nebecc (Crustacean Biology, Ecology and Culture Study Group), Departamento de Zoologia, Instituto de Biociências, C.P. 510, Uni- \\ versidade Estadual Paulista, 18618-000 Botucatu, SP, Brazil \\ ${ }^{\prime}$ Corresponding author. E-mail: mlnf@ibb.unesp.br
}

\begin{abstract}
The juvenile development of Callinectes ornatus was studied from megalopae collected in the neuston off Ubatuba, São Paulo State, Brazil. The animals were raised in the laboratory under constant temperature $\left(25 \pm 1^{\circ} \mathrm{C}\right)$, filtered sea water (35\%o) from the sampling location, and the natural photoperiod. Eleven stages of the juvenile phase were obtained. The main features of the first juvenile stage diagnostic of the species are: the number of segments in the antenna; number of setae on the exopod, endopod, basal endite and coxal endite of the maxilla, on the exopod, endopod, basal endite, coxal endite and epipod of the $1^{\text {st }}$ maxilliped, and on the exopod, endopod and epipod of the $2^{\text {nd }}$ maxilliped. Sexual dimorphism becomes apparent from the fourth juvenile stage onwards.
\end{abstract}

Key words: Portunidae, Callinectes, swimming crab, juvenile stages, morphological characters, sexual dimorphism

\section{Introduction}

Descriptions of species of worldwide brachyurans are based on the morphological characters of adult specimens, because earlier stages of their life cycles are insufficiently known (Fransozo \& Negreiros-Fransozo, 1987). Description of larval or even juvenile stages is commonly done by other specialists.

Because of the difficulty of raising and maintaining young individuals in the laboratory (Fransozo, 1986/ 87), researchers have paid little attention to larval or juvenile development. However, studies of the early stages of crab life cycles are important to improve knowledge of their taxonomy and ecology (NegreirosFransozo et al., 2002), physiology (Anger, 2003) and phylogeny (Marques et al., 2003). Secondary sexual characters appear, through modification of the abdomen and pleopods, during the juvenile stages (Fransozo, 1986/87; Fransozo \& Negreiros-Fransozo, 1987 and Barutot et al., 2001).

Portunids are an important fishery resource, and their commercial exploitation is relevant in the economies of several countries in Europe, Asia and the Americas. People consume these crabs either wild-caught or produced in captivity, such as soft-shell crabs, just after the molt, or ecdysis. In Brazil, only a few wild-caught crabs are consumed (Fernandes et al., 2006).

The family Portunidae Rafinesque, 1815 is represented on the Brazilian coast by 20 native species (Melo, 1996) and an exotic one, Charybdis hellerii (A. Milne-Edwards, 1867) (Negreiros-Fransozo, 1996) in the genera Arenaeus Dana, 1851; Callinectes Stimpson, 1860; Coenophtalmus Milne-Edwards, 1879; Cronius Stimpson, 1860; Laleonectes Manning \& Chace, 1990; Ovalipes Rathbun, 1898; Portunus Weber, 1795; Scylla De Haan, 1833; and Charybdis De Haan, 1833. All of the six local species of genus Callinectes occur off the coast of the state of São Paulo (Melo, 1996). 